\title{
INTERGENTIELE GRONDENREGEL DALAM HUKUM ANTAR TATA HUKUM INTERN TERKAIT KEPEMILIKAN HAK ATAS TANAH BAGI WNI KETURUNAN TIONGHOA DI WILAYAH DIY
}

(Intergentiele Grondenregel in Internal Interlegal Law Regarding Indonesian-Chinese Citizens's Right of Land Ownership in DIY Area)

\author{
Gratianus Prikasetya \\ President University \\ Jl. Ki Hajar Dewantara, Cikarang Baru, Bekasi \\ Email: grat.prikasetya@gmail.com
}

Naskah diterima: 21 Juni 2018; revisi: 20 Agustus 2018; disetujui: 20 Agustus 2018

\begin{abstract}
Abstrak
Tanah memainkan perananan penting dalam pembagunan nasional baik secara yuridis, sosiologis, dan juga finansial di tengah masyarakat. Disamping pengaturan dan praktik unifikasi hukum pertanahan di Indonesia, fenomena pluralisme hukum pertanahan masih terjadi di Wilayah Daerah Istimewa Yogyakarta (DIY). Sebagai sebuah daerah yang memiliki potensi pariwisata yang tinggi, DIY wajib menjamin terlaksananya kepastian hukum dan penegakan hukum khususnya pertanahan. Pluralisme hukum pertanahan di Wilayah ini dapat dilihat dengan masih berlakunya Instruksi Kepala Daerah DIY No K. 898/I/A/1975 disamping UU Nomor 5 Tahun 1960 tentang Pokok-Pokok Agraria. Keberlakuan Instruksi tersebut menyebabkan Warga Negara Indonesia Keturunan Tionghoa tidak dapat mempunyai hak milik atas tanah di Wilayah DIY. Terkait fenomena tersebut, bidang Hukum Antar Tata Hukum (HATAH) Interen memiliki sebuah asas yang dikenal sebagai intergentiele grondenregel. Asas tersebut memungkinkan tanah seolah-olah memiliki golongan masyarakatnya tersendiri dan membawa dampak secara yuridis. Pendekatan berdasarkan asas dalam HATAH Interen ini akan menjadi jembatan guna memfasilitasi pendekatan berdasarkan hukum pertanahan serta perundang-undangan dalam membahas fenomena pertanahan yang terjadi di Wilayah DIY tersebut.
\end{abstract}

Kata Kunci: hukum pertanahan, hak milik, intergentiele grondenregel, hukum antar tata hukum kepastian hukum

\begin{abstract}
Judicially, sociologically, and financially, land plays an important role for national development. Beside the unification regulation and practice in Indonesia Agrarian Law, the phenomenon of legal pluralism is still prevailed in the area of Yogyakarta Special Municipal Region (DIY). DIY as an area that potentially develop in tourism sector has to guarantee the implementation of legal certainty and law enforcement, especially for the agrarian law. The phenomenon of legal pluralism can be felt by the implementation of Governor Instruction No K. 898/I/A/1975 beside Law No 5 Year 1960 Concerning The Principle of Agrarian Law. The Implementation of the Instruction affects that the Indonesian-Chinese Citizen do not have the right to get the land ownership in Yogyakarta Area. According to the phenomenon, The Intern Conflict of Law field offers a principle which known as Intergentiele Grondenregel. That principle gives an authority to a land to have its own nationality and brings judicial consequences. This Intern Conflict of Law approach will be a key to facilitate Agrarian Law Approach and Policies Approach to explain the phenomenon that occurred in DIY.
\end{abstract}

Keywords: Agrarian Law, Land Ownership Right, Intergentiele Grondenregel, Conflict of Law, Legal Certainty. 


\section{A. Pendahuluan}

Sebagai salah satu unsur dalam pembangunan nasional, tanah paling tidak memiliki dua buah fungsi, yaitu fungsi sosial dan fungsi ekonomi. Berdasarkan Undang-Undang Nomor 5 Tahun 1960 tentang Pokok-Pokok Agraria (UU No. 5 Tahun 1960) tanah memiliki sebuah fungsi yang dikenal sebagai fungsi sosial ${ }^{1}$. Fungsi sosial tersebut ialah sebagaimana dijelaskan dalam Ketetapan Majelis Permusyawaratan Rakyat Republik Indonesia (TAP MPR) Nomor II/MPR/1993 tentang Garis-garis Besar Haluan Negara yang antara lain memberi amanat bahwa penataan penguasaan tanah oleh negara diarahkan agar dalam pemanfaatannya dapat mewujudkan keadilan sosial bagi seluruh rakyat Indonesia². Selain fungsi sosial sebagaimana disebutkan diatas, tanah juga memiliki fungsi ekonomis dimana fungsi ekonomis ini apabila dijabarkan secara lebih mendalam erat kaitannya dengan nilai individualisme. Kompleksitas arti tanah bagi masyarakat Indonesia juga pernah dikemukakan oleh Prof. Boedi Harsono sebagai karunia Tuhan Yang Maha Esa kepada bangsa Indonesia yang merupakan salah satu sumber utama bagi kelangsungan hidup dan penghidupan bangsa sepanjang masa dalam mencapai sebesar-besar kemakmuran rakyat yang adil dan merata ${ }^{3}$.

Permasalahan dalam politik pertanahan di Republik Indonesia tidak dapat dilepaskan dari hubungan tarik menarik diantara dua nilai yang terkandung di dalam fungsi tanah. Tanah sebagai perwujudan fungsi sosial cenderung menonjolkan nilaikolektivisme, sedangkantanah sebagai perwujudan fungsi ekonomi cenderung menonjolkan nilai individualisme. Daya tarikmenarik antara dua nilai itulah yang berdampak dalam pembuatan kebijakan dan pelaksanaan politik pertanahan di Indonesia. Fungsi sosial dari tanah berimplikasi pada kewajiban pemerintah Republik Indonesia untuk memanfaatkan penggunaan dan optimalisasi pertanahan di wilayah Indonesia guna kepentingan nasional dan mencapai keadilan sosial bagi seluruh rakyat Indonesia. Hal tersebut dapat dimaknai secara bertolak belakang dengan fungsi ekonomi dari tanah yang berimplikasi pada efisiensi serta eksploitasi tanah yang berada di Wilayah Indonesia demi keuntungan sebesarbesarnya dalam arti materiil. Seiring dengan tujuan tersebut maka Pasal 1 angka 2 UU No. 5 Tahun 1960 memberikan dasar yuridis bahwa seluruh bumi, air, dan angkasa yang terdapat di dalam Wilayah Republik Indonesia merupakan kekayaan nasional ${ }^{4}$. Implikasi dari pengaturan tersebut ialah Pemerintah Indonesia sebagai wakil dari bangsa Indonesia wajib dan berhak untuk mengatur serta menentukan kebijakan pertanahan sejauh di dalam Wilayah Republik Indonesia dan untuk kepentingan seluruh Bangsa Indonesia, oleh karena itu muncul UU No. 5 Tahun 1960 untuk mengatur segala sesuatu yang berkaitan dengan pertanahan di dalam

1 Indonesia, Undang-Undang Tentang Pokok Agraria, Undang-Undang No 5 tahun 1960, LN Tahun 1960 No 10, TLN. No.2043, Pasal 6.

2 Indonesia, Ketetapan Majelis Permusyawaratan Rakyat Tentang Garis-Garis Besar Haluan Negara, TAP MPR Nomor II/MPR/1993, angka 12 huruf f. "Penataan penguasaan tanah oleh negara diarahkan agar pemanfaatannya dapat mewujudkan keadilan sosial bagi seluruh rakyat Indonesia, sedangkan penataan penggunaan tanah dilaksanakan secara berencana guna mewujudkan kemakmuran rakyat yang sebesar-besarnya.

3 Boedii Harsono, Menuju Penyempurnaan Hukum Tanah Nasional, Cet. Kedua, (Jakarta; Penerbit Universitas Trisakti, 2003), hlm. 4.

4 Indonesia, Undang-Undang Tentang Pokok Agraria, Op.Cit, Pasal 1 angka 2. 
Wilayah Republik Indonesia. Hak penguasaan atas tanah yang oleh individu di dalam Wilayah Republik Indonesia berdasarkan pengaturan yang terdapat di dalam UU No. 5 Tahun 1960, dibagi menjadi 5 (lima) macam hak, yakni: ${ }^{5} \mathrm{Hak}$ milik; Hak guna usaha; Hak guna bangunan; Hak pakai; Hak sewa; Hak membuka tanah; dan Hakhak lain yang tidak termasuk dalam hak-hak tersebut diatas yang akan ditetapkan dengan Undang-Undang serta hak-hak yang sifatnya sementara sebagai yang disebutkan dalam Pasal 31.

Daya tarik menarik antara fungsi sosial dan fungsi ekonomi tersebut dapat dilihat secara lebih kontekstual pada fenomena yang terjadi di Wilayah Daerah Istimewa Yogyakarta (DIY). Pada tahun 2012 melalui Surat Keterangan No: 593/00531/RO.l/2012 tertanggal 8 Mei 2012 Pemerintah Provinsi DIY menerangkan beberapa hal terkait hak atas tanah bagi Warga Negara Indonesia (WNI) Keturunan Tionghoa di Wilayah DIY sebagai berikut: ${ }^{6}$

1) Instruksi Kepala Daerah DIY No. K.898/ I/A/1975 tanggal 5 Maret 1975 sampai saat ini masih berlaku dan merupakan affirmative policy yang tujuannya untuk melindungi warga pribumi agar kepemillikan tanah tidak beralih kepada warga atau pemodal yang secara finansial memiliki kemampuan lebih atau kuat.

2) Filosofi terbitnya Instruksi Kepala Daerah DIY No K. 898/I/A/1975 tanggal 5 Maret 1975 adalah:

a) Sebagian besar perolehan tanah milik warga di DIY asal usulnya adalah tanah pemberian dari Keraton Yogyakarta. b) Pada zaman perjuangan kemerdekaan, warga Tionghoa meminta perlindungan kepada Sri Sultan HB IX dan tertuang dalam prasasti di Kraton yang ditandatangani oleh masyarakat Tionghoa saat itu serta ada monument "ngejaman" sebagai hadiah dari warga keturunan Tionghoa.

3) Pernah dilakukan gugatan perkara Kasasi Tata Usaha Negara oleh H. Budi Styagraha terhadap Instruksi Kepala Daerah DIY No K. 898/I/A/1975 tanggal 5 Maret 1975 dan telah ada putusan Mahkamah Agung RI Reg. Nomor 281K/TUN/2001 yang menolak permohonan kasasi tersebut, sehingga mempunyai kekuatan hukum yang pasti. Secara yuridis formal Instruksi Kepala Daerah DIY tersebut masih berlaku dan memiliki daya.

Alasan sebagaimana dijelaskan dalam poin nomor 1 Surat Keterangan tertanggal $8 \mathrm{Mei}$ 2012 tersebut merupakan wujud tarik-menarik antara 2 fungsi tanah yakni sebagai fungsi sosial dan fungsi ekonomi. Pemerintah Provinsi DIY melalui Surat Keterangan tersebut secara tersirat memperlihatkan sifat protektifnya yang apabila diteliti dan dilihat secara teoritis kebijakan yang dibuat tersebut bertentangan dengan prinsip fungsi ekonomis dari tanah dan lebih condong ke fungsi sosial dari tanah. Selain faktor nilai-nilai, dalam keterangan tersebut terdapat satu buah kebijakan yakni Instruksi Kepala Daerah DIY No. K. 898/I/A/1975 yang dianggap masih berlaku sampai dengan saat ini sehingga WNI Keturunan Tionghoa di Wilayah DIY tidak berhak mendapatkan hak milik atas

Ibid, Pasal 16 ayat (1).

Surat Keterangan Pemerintah Provinsi DIY No: 593/00531/RO.I/2012, tertanggal 8 Mei 2012. 
tanah, padahal saat ini Instruksi tersebut sudah tidak relevan dan tidak sesuai dengan ketentuan dalam UU No. 5 Tahun 1960.

Terkait Instruksi Kepala Daerah DIY No K. 898/I/A/1975 dapat digunakan tiga pendekatan guna mengkaji keberlakuannya yakni pendekatan normatif melalui kajian IImu Perundang-undangan, pendekatan empiris melalui metode socio-legal, dan pendekatan normatif melalui cabang ilmu hukum yakni Hukum Antar Tata Hukum. Kajian normatif melalui pendekatan Ilmu Perundang-undangan dapat digunakan untuk mangkaji keberlakuan norma hukum yakni Instruksi Kepala Daerah DIY No K. 898/I/A/1975 yang harus sesuai dengan peraturan perundang-undangan lain terlebih yang bersifat lebih tinggi. Hal ini dapat dilakukan dengan mendasarkan kajian pada ketentuan dalam Pasal 7 ayat (1) Undang-Undang Nomor 12 Tahun 2011 tentang Pembentukan Peraturan Perundang-Undangan (UU No. 12 Tahun 2011) yang mengatur hierarki peraturan perundangundangan. Pendekatan empiris melalui metode sosio-legal dapat digunakan guna melihat efektifitas norma-norma hukum positif yang berlaku di Wilayah DIY.7 Pendekatan normatif melalui cabang ilmu hukum Hukum Antar Tata Hukum (HATAH) diharapkan mampu melengkapi kedua pendekatan terdahulu khususnya terkait unsur pilihan hukum yang yang terjadi di dalam realita praktik pertanahan di Wilayah DIY. Oleh karena itu pembahasan pada artikel ini akan dibatasi pada penjelasan akan pertanyaan bagaimanakah penerapan asas Intergentiele Grondenregel dalam Hukum Antar Tata Hukum
Intern terkait dengan kepemilikan hak atas tanah bagi WNI Keturunan Tionghoa di Wilayah DIY?

\section{B. Metode Penelitian}

Guna mencapai kesimpulan terkait topik yang dikemukakan oleh penulis, tulisan ini menggunakan penelitian hukum yuridisnormatif yang difokuskan pada kajian normanorma hukum terkait pertanahan di Wilayah DIY yang dikaitkan dengan teori-teori Hukum Antar Tata Hukum ${ }^{8}$. Data sekunder akan digunakan dalam tulisan ini yang terdiri atas data-data yang tidak didapatkan langsung dari masyarakat seperti peraturan perundang-undangan dan teori-teori yang didapatkan dari buku teks. Data-data sekunder sebagaimana dimaksud ialah termasuk ke dalam kategori bahan hukum primer dan bahan hukum sekunder. Tulisan ini akan dimulai dengan pembahasan dan uraian mengenai kebijakan pertanahan di wilayah DIY yang meliputi sejarah dan keunikan kebijakan pertanahan di wilayah DIY. Kemudian terkait fenomena yang terjadi tersebut, penulis akan mengaitkannya dengan teori-teori yang terdapat di dalam HATAH khususnya HATAH Interen di Indonesia.

\section{Pembahasan}

\section{Kebijakan Pertanahan Nasional}

Setelah Indonesia merdeka pada tahun 1945 untuk pertama kalinya pemerintah Republik Indonesia berhasil membuat peraturan mengenai agraria pada tahun 1960. Peraturan

Sulistyowati Irianto dan Lim Sing Meij, "Praktik Penegakan Hukum: Arena Penelitian Sosiolegal yang Kaya,", dalam Metode Penelitian Hukum Konstelasi dan Refleksi, ed. Sulistyowati Irianto dan Sidharta (Jakarta: Yayasan Pustaka Obor Indonesia, 2013), hlm. 191.

8 Soerjono Soekanto, Pengantar Penelitian Hukum (Jakarta: UI Press, 2010), hal. 52. 
tersebut adalah UU Nomor 5 Tahun 1960 tentang Peraturan Dasar Pokok-Pokok Agraria, Lembaran Negara Republik Indonesia Nomor 104 Tahun 1960. Dengan berlakunya UU No. 5 Tahun 1960 terjadi perubahan fundamental pada hukum pertanahan di Indonesia yang meliputi struktur perangkat hukum, konsepsi yang mendasari, maupun isinya yang ditujukan untuk kepentingan umum dan menyesuaikan kondisi setelah Indonesia merdeka sebagaimana dituangkan dalam Bagian Pendapat "UU No 5 Tahun 1960 harus sesuai dengan kepentingan Rakyat Indonesia serta memenuhi pula keperluannya menurut permintaan zaman". Adapun tujuan dari dibentuknya hukum pertanahan nasional ini adalah: ${ }^{9}$

a) meletakan dasar-dasar bagi penyusunan hukum agraria nasional yang akan merupakan alat untuk membawakan kemakmuran, kebahagiaan, dan keadilan bagi negara dan rakyat, terutama rakyat tani, dalam rangka masyarakat yang adil dan makmur;

b) meletakan dasar-dasar untuk mengadakan kesatuan dan kesederhanaan dalam hukum pertanahan;

c) meletakan dasar-dasar untuk memberikan kepastian hukum mengenai hak-hak atas tanah bagi rakyat seluruhnya.

Ketiga tujuan tersebut di atas diwujudkan dalam asas-asas UU No. 5 Tahun 1960 sebagai berikut: ${ }^{10}$

a) Asas Kenasionalan, asas ini tertuang dalam Pasal 1-Pasal 3 UU No. 5 Tahun 1960.

b) Asas Dikuasai Oleh Negara, asas ini ditemukan dalam pasal 2 ayat (1) UU No. 5
Tahun 1960 yang menyatakan "Atas dasar ketentuan dalam Pasal 33 ayat (3) Undangundang Dasar NRI dan hal-hal sebagai yang dimaksud dalam Pasal 1, bumi, air dan ruang angkasa, termasuk kekayaan alam yang terkandung didalamnya itu pada tingkatan tertinggi dikuasai oleh Negara, sebagai organisasikekuasaanseluruh rakyat." Adapun maksud dikuasai oleh negara diartikan sebagai negara memiliki kewenangan untuk mengatur dan menyelenggarakan peruntukan, penggunaan, persediaan dan pemeliharaannya, menentukan dan mengatur hak-hak yang dapat dipunyai atas (bagian dari) bumi, air dan ruang angkasa itu, serta menentukan dan mengatur hubungan-hubungan hukum antara orangorang dan perbuatan-perbuatan hukum yang mengenai bumi, air dan ruang angkasa.

c) Asas Fungsi Sosial Hak-hak Atas Tanah, asas ini tertuang pada Pasal 6 UU No. 5 Tahun 1960 yang menyatakan "Semua hak atas tanah mempunyai fungsi sosial" asas ini berarti bahwa hak atas tanah apapun yang ada pada seseorang, tidaklah dapat dibenarkan, bahwa tanahnya itu akan dipergunakan (atau tidak dipergunakan) semata-mata untuk kepentingan pribadinya, terlebih kalau hal itu menimbulkan kerugian bagi masyarakat atau melanggar kepentingan umum dan Undang-Undang.

d) Asas Kesatuan Hukum, pada UU No. 5 Tahun 1960 merupakan unifikasi dan kodifikasi di dalam sistem hukum pertanahan di Indonesia.

e) Asas Kepastian Hukum dan Perlindungan Hukum, asas ini tertuang pada Pasal 19 ayat

9 Indonesia, Undang-Undang Tentang Pokok Agraria, Op. Cit, Penjelasan Umum angka I.

10 Urip Santoso, Hukum Agraria: Kajian Komprehensif, (Jakarta: Kencana, 2013), hlm. 54. 
(1) UU No. 5 Tahun 1960 yang menyatakan bahwa "Untuk menjamin kepastian hukum oleh Pemerintah diadakan pendaftaran tanah diseluruh wilayah Republik Indonesia menurut ketentuan-ketentuan yang diatur dengan Peraturan Pemerintah", asas ini juga ditemukan pada Pasal 18 UU No. 5 Tahun 1960 yang menyatakan "Untuk kepentingan umum, termasuk kepentingan bangsa dan Negara serta kepentingan bersama dari rakyat, hak-hak atas tanah dapat dicabut, dengan memberi ganti kerugian yang layak dan menurut cara yang diatur dengan Undang-undang."

f) Asas Pemisahan Horisontal, di dalam UUPA dikenal pemisahan antara kepemilikan bangunan dan tanah atau kepemilikan pohon dan tanah. Artinya seseorang dapat melakukan perjanjian atau pengalihan hak atas tanah, atas bangunan, dan/atau pohon serta tanah.

\section{Sejarah dan Perkembangan Hukum Pertanahan di DIY}

Penjelasan mengenai sejarah dan perkembangan kebijakan pertanahan di Wilayah DIY harus dibatasi yakni mulai saat perjanjian Giyanti dibuat pada tahun 1755, sebab sebelum Perjanjian Giyanti dibuat belum terdapat kekuasaan Kesultanan Ngayogyakarta Hadiningrat melainkan masih kekuasaan Kerajaan Mataram Islam dan pendahulunya, yang tidak memiliki korelasi dengan kebijakan pertanahan di masa kekuasaan Kesultanan Ngayogyakarta Hadiningrat ${ }^{11}$. Kebijakan yang mengatur soal pertanahan di Wilayah Kesultanan Yogyakarta menurut waktunya dapat dibagi menjadi dua masa yakni masa sebelum kemerdekaan Republik Indonesia dan masa Pasca Kemerdekaan Republik Indonesia.

\section{a. Sebelum Kemerdekaan}

Setelah Perjanjian Giyanti yang membagi dua wilayah Kerajaan Mataram, Inggris kemudian mulai masuk untuk menggantikan kekuasaan Belanda di Wilayah Indonesia. Pada masa kekuasaan Inggris yaitu saat Letnan Thomas Stamford Raffles menjadi gubernur wilayah Kesultanan Ngayogyakarta Hadiningrat kemudian dipecah lagi menjadi wilayah Kesultanan dan Wilayah Pakualaman ${ }^{12}$. Perihal kebijakan penguasaan tanah pun tetap mengikuti hasil dari Perjanjian Giyanti yakni Sri Sultan Hamengku Buwono mempunyai hak milik (domein) atas tanah di wilayah barat kerajaan Mataram dan hal ini tetap harus hidup dalam kesadaran hukum masyarakat yang menyebabkan masyarakat tidak dapat memiliki hak eigendom atas tanah ${ }^{13}$. Adapun sebagai penguasa tertinggi di Wilayah Kesultanan Ngayogyakarta Hadiningrat Sultan telah menetapkan hak-hak atas tanah yang dapat dimiliki oleh masyarakat sebagai berikut: Hak anggaduh; Hak anggaangga; Hak andarbeni; Hak pungut hasil; Hak didahulukan; dan Hak blengket.

Kebijakan tersebut dituangkan oleh Sultan secara sepihak melalui Rijksblaad. Rijksblaad adalah istilah bagi aturan hukum yang berlaku di Wilayah Kesultanan dan Pakualaman dengan

11 Kus Sri Antoro, "Analisis Substansi dan Implementasi Undang-Undang No 13 Tahun 2012 Tentang Keistimewaan DIY dalam Bidang Pertanahan". Dlm Bhumi, Jurnal Agraria dan Pertanahan, (Yogyakarta: Pusat Penelitian dan Pengabdian Masyarakat Sekolah Tinggi Pertanahan Nasional, 2015), hlm. 18.

12 Ibid, Hal 6

13 Ibid. 
persetujuan pemerintah kolonial ${ }^{14}$. Dalam bidang pertanahan dikenal ada dua Rijksblaad yang penting yakni Rijksblaad Kesultanan No. 16 Tahun 1918 dan Rijksblaad Pakualaman No. 18 Tahun 1918. Dalam Rijksblaad itu diatur: "Sakabehing bumi kang ora ana tandha yektine kadarbe ing liyan mawa wewenang eigendom, dadi bumi kagungane keratin ingsun"15. Artinya semua tanah yang tidak ada bukti kepemilikan menurut hak eigendom (hak milik menurut Agrarische Wet 1870), maka tanah itu adalah milik raja. Atas dasar kedua Rijksblaad tersebut maka munculah sebutan tanah swapraja di Wilayah Yogyakarta yang dianggap masih ada sampai saat ini. Dewasa ini tanah swapraja itu dikenal dengan istilah Sultanaat Ground dan Pakualaman Grond. Kedua jenis hak itu kedudukan sama seperti Domein Verklaring. Perihal Domein Verklaring ini diatur dalam Agrarische Wet 1870 yaitu Staatsblad 1870 No. 55 yang berbunyi "Semua tanah yang orang lain tidak dapat membuktikannya, bahwa itu eigendomnya adalah domein atau milik Negara." ${ }^{\prime 16}$

\section{b. Masa Kemerdekan}

Setelah proklamasi kemerdekaan pada tanggal 17 Agustus 1945, Kesultanan
Ngayogyakarta Hadiningrat mengeluarkan amanat pada tanggal 5 September 1945 sebagaimana telah disebutkan sebelumnya. Inti dari amanat tersebut ialah pernyataan Sultan Hamengku Buwono sebagai pemimpin daerah Ngayogyakarta Hadiningrat memilih untuk menyatu menjadi wilayah Republik Indonesia ${ }^{17}$. Setelah dikeluarkan amanat tersebut, pada tahun 1950 Pemerintah Republik Indonesia mengeluarkan Undang-Undang No. 3 Tahun 1950 (untuk selanjutnya disebut UU No. 3 Tahun 1950) tentang Pembentukan Daerah Istimewa Jogjakarta. Pasal 1 UU No. 3 Tahun 1950 ini menyatakan secara tegas bahwa Daerah Istimewa Jogjakarta terdiri atas daerah Kesultanan Jogjakarta dan Daerah Paku Alaman ${ }^{18}$. Untuk urusan yang berkaitan dengan pertanahan di Wilayah DIY juga ditegaskan dalam Pasal 4 yang mengatur bahwa hal yang berkaitan dengan pertanahan atau agraria termasuk ke dalam urursan Rumah Tangga DIY ${ }^{19}$.

Pasal 4 UU No. 3 Tahun 1950 ini merupakan dasar hukum yang diberikan oleh UndangUndang kepada Pemerintah DIY untuk berhak mengatur sendiri perihal kebijakan yang berkaitan dengan pertanahan. Adapun dasar hukum yang digunakan pemerintah DIY untuk mengatur pertanahan ialah Pasal 4 Agrarische

\footnotetext{
Ibid, hlm. 21.

15 Rijksblaad No 16 dan No 18 tahun 1918.

16 http://suaraagraria.com/tag-14859-domein-verklaring.html, diakses pada 29 Oktober 2015.

17 Maklumat 5 September 1945; isinya sebagai berikut AMANAT SRI PADUKA INGKENG SINUWUN KANGDJENG SULTAN: Kami Hamengku Buwono IX, Sultan Negeri Ngajogjakarta Hadiningrat menjatakan:1. Bahwa Negeri Ngajogjakarta Hadiningrat jang bersifat keradjaan adalah daerah istimewa dari Negara Republik Indonesia; 2. Bahwa kami sebagai Kepala Daerah memegang segala kekuasaan dalam Negeri Ngajogjakarta Hadiningrat, dan oleh karena itu berhubung dengan keadaan pada dewasa ini segala urusan pemerintahan dalam Negeri Ngajogjakarta Hadiningrat mulai saat ini berada ditangan kami dan kekuasaan-kekuasaan lainnja kami pegang seluruhnya.;3. Bahwa perhubungan antara Negeri Ngajogjakarta Hadiningrat dengan Pemerintah Pusat Negara Republik Indonesia, bersifat langsung dan Kami bertanggung djawab atas Negeri Kami langsung kepada Presiden Republik Indonesia. Kami memerintahkan supaja segenap penduduk dalam Negeri Ngajogjakarta Hadiningrat mengindahkan Amanat Kami ini. Ngajogjakarta Hadiningrat, 28 Puasa Ehe 1876 atau 5-9-1945.

18 Indonesia, Undang-Undang Tentang Pembentukan Peraturan Perundang-Undangan, Undang-Undang UU No 12 Tahun 2011, LN Tahun 2011 No 82 TLN. 5234, Pasal 1.

19 Ibid. Pasal 4.
} 
Wet $1870^{20}$. Sebagai pelaksanaan dari UU No. 3 Tahun 1950 dibentuklah Peraturan Daerah DIY No. 5 Tahun 1954 tentang Hak Atas Tanah di DIY (untuk selanjutnya disebut Perda DIY No. 4 Tahun 1954) yang isinya antara lain: ${ }^{21}$

1) Hak atas tanah di Kota Praja Yogyakarta buat sementara masih berlaku Rijksblaad Kasultanan No 23 Tahun 1925 dan Rijksblaad Paku Alaman No. 25 Tahun 1925 (Pasal 2).

2) DIY memberikan hak milik perseorangan turun-temurun (erfelijk individueel bezitsrecht) atas sebidang tanah kepada WNI, dengan tanda hak milik (Pasal 4)

3) Kelurahan sebagai badan hukum mempunyai hak milik atas tanah, yang disebut tanah desa, dengan fungsi meliputi: Lungguh, Kas Desa, dan Pengarem-arem (Pasal 6).

4) Hak memakai turun temurun menjadi hak milik (Pasal 10).

Seiring berjalannya waktu selanjutnya pada tahun 1960 pemerintah Republik Indonesia melakukan unifikasi dibidang hukum pertanahan yang mengakibatkan lahirnya Undang-Undang No. 5 Tahun 1960. Kemudian baru pada tahun 1984 melalui Keputusan Presiden No. 33 Tahun 1984 tentang Pemberlakuan Sepenuhnya Undang-Undang Nomor 5 Tahun 1960 di Wilayah DIY (Keppres No. 33 Tahun 1984), UU No. 5 Tahun 1960 dinyatakan sepenuhnya berlaku di Wilayah DIY dan mengamanatkan bahwa segala kebijakan pertanahan di dalam Wilayah DIY harus sesuai dengan pengaturan dalam UU No. 5 Tahun 1960.

\section{Penerapan UU No. 5 Tahun 1960 di Wilayah DIY}

Penerapan UU No. 5 Tahun 1960 di Yogyakarta baru dilakukan secara penuh pada tahun 1984 dengan dikeluarkannya Perda DIY Nomor 3 Tahun 1984 yang mengatur tentang Pelaksanaan Berlaku Sepenuhnya UndangUndang Nomor 5 tahun 1960 di Provinsi DIY. Adapun Perda ini muncul sebagai konsekuensi terbitnya Keputusan DPRD Provinsi DIY Nomor 3/K/DPRD/1984 yang berisikan pernyataan Permerintah Provinsi DIY untuk memberlakukan secara penuh UU No. 5 Tahun 1960 di Wilayah DIY serta adanya Keputusan DPRD Provinsi DIY Nomor 4/K/DPRD/1984 yang berisikan usul kepada pemerintah Republik Indonesia untuk mengeluarkan Keputusan Presiden yang memberlakukan secara penuh UU No. 5 Tahun 1960 di Wilayah DIY. Berdasarkan dua keputusan DPRD tersebut dapat dilihat intensi dari Pemerintah Provinsi DIY pada waktu itu untuk tunduk dan memberlakukan dan menyeragamkan kebijakan pertanahan di Wilayah DIY dengan menggunakan UU No. 5 Tahun 1960.

Dengan adanya permintaan sebagaimana dinyatakan dalam Keputusan DPRD tersebut, pemerintah mengeluarkan Keputusan Presiden Republik Indonesia Nomor 33 Tahun 1984 yang isinya mengenai pemberlakuan UU No. 5 Tahun 1960 di Wilayah DIY. Oleh karenanya sejak saat itu UU No. 5 Tahun 1960 berlaku sah dan mengikat di Wilayah DIY sehingga kebijakan soal pertanahanyangtadinyaberdasarkanwewenang otonomi sebagaimana diatur dalam UU No. 3 Tahun 1950 berubah pengurusannya menjadi 
berdasarkan wewenang dekonsentrasi ${ }^{22}$. Kemudian berdasarkan Pasal 3 Perda DIY Nomor 3 Tahun 1984 ini juga ditegaskan bahwa setelah berlakunya Peraturan Daerah tersebut, segala ketentuan peraturan perundang-undangan DIY yang mengatur tentang agraria dinyatakan tidak berlaku lagi. ${ }^{23}$

Pada tahun 1975 tepatnya pada tanggal 5 Maret 1975, Kepala Daerah Istimewa Yogyakarta (DIY) yang pada saat itu diwakili oleh Wakil Kepala DIY yakni Paku Alam VIII mengeluarkan sebuah instruksi, yakni Instruksi Kepala Daerah DIY No K. 898/I/A/1975. Instruksi ini intinya ditujukan kepada Bupati/Walikota Kepala Daerah di seluruh Wilayah DIY yang isinya berupa instruksi agar seluruh kepalakepala daerah sebagaimana dimaksud diatas melakukan penyeragaman policy pemberian hak atas tanah kepada Warga Negara Indonesia (WNI) non pribumi yang memiliki hak milik atas tanah rakyat agar melepaskan hak miliknya tersebut melalui pelepasan hak dan kemudian setelah dilepaskan hak miliknya warga negara Indonesia non pribumi tersebut dapat mengajukan permohonan kepada kepala daerah DIY agar mendapatkan hak lain ${ }^{24}$.

\section{Kebijakan Pertanahan di DIY berdasarkan Instruksi Kepala Daerah DIY No K. 898/I/A/1975}

Pada prinsipnya, Instruksi Kepala Daerah DIY No No. K.898/I/A/1975 tersebut merupakan pengaturan pelayanan pertanahan yang berlaku di wilayah DIY. Sesuai Instruksi tersebut, WNI golongan Tionghoa di Kota Yogyakarta tidak dapat memiliki hak milik atas tanah. WNI golongan Tionghoa di Kota Yogyakarta hanya diberi Hak Guna Bangunan, Hak Pakai, dan Hak Guna Usaha. Pada intinya ketentutan tersebut berbunyi, "Apabila ada seorang Warga Negara Indonesia non Pribumi membeli tanah hak milik rakyat, hendaknya diproseskan sebagaimana biasa, ialah dengan melalui pelepasan hak, sehingga tanahnya kembali menjadi tanah negara yang dikuasai langsung oleh Pemerintah Daerah Istimewa Yogyakarta DIY dan kemudian yang berkepentingan/melepaskan supaya mengajukan permohonan kepada Kepala Daerah DIY untuk mendapatkan sesuatu hak". Artinya, kebijakan pemerintahan DIY menentukan bahwa untuk golongan Tionghoa tidak dapat memperoleh hak milik atas tanah di wilayah DIY. Peraturan ini berlaku sampai ada peraturan yang menggantikannya dan/atau membatalkan keberlakuannya. Dalam realita, Instruksi Kepala Daerah DIY No K. 898/I/A/1975 ini tetap berlaku meskipun pada tahun 1984 Yogyakarta secara formal hukum pertanahannya mengacu kepada UUPA.

Ketentuan ini mempengaruhi kebijakan pelayanan pertanahan bagi WNI golongan Tionghoa yang mengajukan permohonan hak pertama kali, peralihan, perpanjangan, maupun pembaharuan hak. Kantor Pertanahan Kota Yogyakarta memberikan hak atas tanah berupa

\footnotetext{
22 Yogyakarta, Peraturan Daerah Tentang Pelaksanaan Berlaku Sepenuhnya Undang-Undang No 5 Tahun 1960 di Propinsi DIY, Op.Cit, Huruf C.

23 Ibid, Pasal 3..

24 Yogyakarta, Surat Instruksi Kepala Daerah Istimewa Yogyakarta No K. 898/I/A/1975, Surat Instruksi Mengenai Penyeragaman Policy Pemberian Hak Atas Tanah Kepada Seorang WNI non Pribumi, tertanggal 5 Maret 1975.
} 
HGB, Hak Pakai, dan hak lainnya. ${ }^{25}$ Adapun parameter yang digunakan untuk menentukan apakah seseorang itu golongan Tionghoa atau bukan dapatlah dikatakan tidak ada, dan hanya berdasar penampakan fisik sang pemohon dan juga unsur yang terkandung dalam nama si pemohon. Tidak adanya parameter yang pasti guna menentukan apakah seorang pemohon merupakan WNI keturunan Tionghoa atau bukan juga menjadi permasalahan dalam kebijakan pertanahan di wilayah Provinsi DIY.

Kondisi tersebut dapat kita lihat dari pengalaman beberapa orang warga golongan Tionghoa yang melakukan proses pendaftaran hak atas tanah dan hanya memperoleh maksimal HG, sebagaimana terinci dalam tabel sebagai berikut: ${ }^{26}$
Dari data tersebut, keterangan pejabat BPN, serta Surat Keterangan yang dibuat oleh Pemerintah Daerah Provinsi DIY memperlihatkan bahwa secara yuridis maupun secara sosiologis Instruksi Kepala Daerah DIY No No. K.898/I/A/1975 masih berlaku di Wilayah DIY dan menjadi dasar pembatasan bagi warga keturunan Tionghoa untuk memperoleh hak milik atas tanah di Wilayah DIY.

Berdasarkan Surat Keterangan yang dikeluarkan Pemerintah Provinsi DIY tertanggal 8 Mei 2012, No. 593/00531/RO.I/2012, terdapat beberapa alasan mengapa warga Tionghoa tidak dapat memiliki hak milik atas tanah, alasanalasan tersebut antara lain:27

\begin{tabular}{clll}
\hline No. & Nama & Alamat & Hak atas Tanah yang diperoleh \\
\hline 1. & Hindra Gunawan & Jl. P. Mangkubumi 19-A Yogyakarta & HGB \\
\hline 2. & Hetty Hartono & Jl. K.H. A. Dahlan 67, Yogyakarta & HGB \\
\hline 3. & Suryo Wijoyo & Jl. K.H. A. Dahlan 68, Yogyakarta & HGB \\
\hline 4. & Paula & Jl. K.H. A. Dahlan 47, Yogyakarta & HGB \\
\hline 5. & Cristin Juliana & Jl. Pajeksan 35 Yogyakarta & HGB \\
\hline 6. & Natalia Wijanarko & Jl. Pajeksan 54 Yogyakarta & HGB \\
\hline 7. & Tan Bian Hong & Jl. Pajeksan 52 Yogyakarta & HGB \\
\hline 8. & Lie Siauw Pa & Pasar Beringharjo & HGB \\
\hline 9. & Liam Mie Hwa & Pasar Beringharjo RB-105 & HGB \\
\hline 10. & Hiu Yauw T & Jl. Malioboro 17 Yogyakarta & HGB \\
\hline 11. & Thomas Kurniawan & Pasar Beringharjo Los kain. & HGB \\
\hline
\end{tabular}


a) Instruksi Kepala Daerah DIY No K. 898/I/A/1975 sampai saat ini masih berlaku dan merupakan affirmative policy yang tujuannya untuk melindungi warga pribumi agar kepemillikan tanah tidak beralih kepada warga atau pemodal yang secara finansial memiliki kemampuan lebih atau kuat.

b) Filosofi terbitnya Instruksi Kepala Daerah DIY No K. 898/I/A/1975 adalah:

1) Sebagian besar perolehan tanah milik warga di DIY asal usulnya adalah tanah pemberian dari Kraton Yogyakarta.

2) Pada zaman perjuangan kemerdekaan, warga Tionghoa meminta perlindungan kepada Sri Sultan HB IX dan tertuang dalam prasasti di Kraton yang ditandatangani oleh masyarakat Tionghoa saat itu serta ada monumen "ngejaman" sebagai hadiah dari warga keturunan Tionghoa.

c) Pernah dilakukan gugatan perkara Kasasi Tata Usaha Negara oleh H. Budi Styagraha terhadap Instruksi Kepala Daerah DIY No K. 898/I/A/1975 dan telah ada putusan Mahkamah Agung RI Reg. Nomor 281K/ TUN/2001 yang menolak permohonan kasasi tersebut, sehingga mempunyai kekuatan hukum yang pasti. Secara yuridis formal Instruksi Kepala Daerah DIY tersebut masih berlaku dan memiliki daya mengikat.

\section{Implementasi Instruksi Kepala Daerah DIY No. K.898/I/A/1975 oleh Badan Pertanahan Nasional Kantor Wilayah (BPN Kanwil) DIY28}

Implementasi Instruksi Kepala Daerah DIY No K. 898/I/A/1975 ini sebenarnya telah disadari oleh aparat BPN bahwa berdasarkan teori dalam Peraturan Perundang-undangan (khusus dalam hal kepemilikan atas tanah), peraturan yang lebih rendah harus sesuai dengan peraturan yang lebih tinggi, tidak berlaku di DIY. Hal in senada dengan fenomena yang dideskripsikan di dalam surat kabar Jakarta Post ${ }^{29}$ yang pada intinya menyatakan bahwa pelarangan pemilikan hak atas tanah oleh WNI golongan Tionghoa bertentangan dengan prinsip-prinsip $\mathrm{HAM}^{30}$.

Terkait dengan kebijakan pertanahan yang dikeluarkan oleh Sultan, BPN sebenarnya tetap mendorong agar semua kebijakan pertanahan di DIY kembali kepada norma-norma yang diatur dalam UUPA. Namun hal itu tidak mudah dilaksanakan di karena ada "tekanan" dari dalam, terlebih dari aspek kultural setempat. Diakui oleh BPN bahwa sejak dahulu memang golongan Tionghoa tidak diberikan Hak Milik, sehingga jika mereka membeli tanah-tanah adat, maka status tanah tersebut harus diturunkan menjadi Hak Guna Bangunan, meskipun DIY secara deklaratif kebijakan pertanahannya menundukan diri kepada UU Pokok Agraria pada tahun 1984 dengan diterbitkannya Perda DIY No. 3 Tahun 1984 tentang Pelaksanaan Berlaku Sepenuhnya UU No. 5 Tahun 1960 di Propinsi DIY. Namun saat ini istilah tanah negara yang

\footnotetext{
Wawancara dengan Kepala Bagian Pemberian Hak atas Tanah BPN Kanwil DIY (Bpk. Suardi).

29 Jakarta Post, 25 Agustus 2015, "Yogya Urge to Drop Notorious Land Policy", "discriminatory land policy prohibits non-indigenous citizens from owning land in Yogyakarta, Komnas HAM deems policy unconstitutional, ChineseIndonesian in the city are granted right to build license (HGB) which they must extent every 20 years."

30 Lampiran XII, Op. Cit.
} 
dikuasai oleh Pemda DIY dinilai tidak berlaku lagi dan seluruh tanah di Wilayah DIY menjadi tanah milik Kesultanan. Dalam praktiknya, pembatasan pemberian hak atas tanah di DIY kerap dikaitkan dengan Undang-Undang Keistimewaan DIY yang memberikan legitimasi bagi pemerintah DIY untuk mengatur sendiri soal kebijakan pertanahan termasuk dalam pembatasan pemberian hak atas tanah bagi WNI keturunan Tionghoa. Pembatasan ini erat kaitannya dari aspek historis Wilayah DIY yang buktinya dapat dilihat pada prasasti Tionghoa ${ }^{31}$.

BPN sebagailembaga negarayang seharusnya memiliki kewenangan dalam pemberian hak atas tanah tidak dapat melakukan fungsinya secara optimal dikarenakan adanya pranata lain yang mengatur hal yang sama, yaitu Paniti Kismo yang berada di bawah lembaga Kesultanan. Paniti Kismo memiliki status sebagai kantor pertanahan Kesultanan yang berada di wilayah DIY, khususnya bagi tanah-tanah Sultanaat Grond (SG) dan Pakualam Grond (PG). Dalam hal ini, Paniti Kismo berperan mengatur dan memberikan izin pakai terhadap penggunaan tanah-tanah DIY yang diklaim sebagai tanah Sultan dan tanah Pakualam. Akibatnya, peranan BPN dalam bidang pertanahan hanya bisa memberikan perpanjangan hak atas tanah golongan Tionghoa apabila sudah mendapatkan cap dari Paniti Kismo. Situasi ini menempatkan BPN pada situasi dilematis, dimana pada satu sisi ia harus mengikuti kebijakan pemerintah pusat, di sisi lain mereka harus mengikuti kebijakan lokal sebagaimana dalam praktik pertanahan di DIY lebih tunduk kepada peraturan yang dikeluarkan oleh Sultan. Hal ini diakui oleh BPN merupakan permasalahan umum yang dihadapi di daerah-daerah otonomi seperti Aceh dan Papua.

Permasalahan sebagaimana diuraikan di atas akan terselesaikan apabila Peraturan Daerah mengenai Keistimewaan (Perdais) di DIY telah selesai disusun dan mulai berlaku, karena Perdais tersebut merupakan pelaksanaan teknis dari Undang-Undang Keistimewaan DIY yang akan mengatur hal-hal praktis termasuk praktik pertanahan di Wilayah DIY. Perdais yang tengah dirancang nantinya akan mengatur dan memberikan kekuasaan kepada Keraton Kesultanan Yogyakarta dan Puro Pakualaman untuk mengurus tanah-tanah milik keraton (SG dan PG).

BPN Kanwil DIY telah menyarankan sejak dua tahun lalu agar pembatasan pemberian hak atas tanah terhadap masyarakat Tionghoa ini dirubah melalui solusi apabila tanah yang akan digunakan untuk berusaha maka akan diberikan HGB namun apabila hanya untuk tempat tinggal akan diberikan Hak Milik. Solusi dan saran yang diberikan oleh BPN saat ini tengah dalam pertimbangan gubernur dan juga DPRD setempat. Praktik pembatasan pemberian hak milik atas tanah bagi WNI keturunan Tionghoa pun tidak luput dari kesalahan, sebab sampai dengan saat ini parameter yang menunjukkan bahwa yang bersangkutan termasuk keturunan Tionghoa tidak diatur secara jelas dan bahkan tidak ada. Biasanya untuk menentukan apakah masyarakat keturunan Tionghoa hanya dilihat dari dokumen-dokumen dan silsilah keluarga yang bersangkutan.

BPN Kanwil DIY sebagai otoritas pemerintah yang memiliki wewenang soal pertanahan saat ini berada dalam posisi yang dilematis karena di

31 Prasasti Tionghoa merupakan sebuah prasasti yang terletak di halaman Kraton Yogyakarta yang berisikan ucapan terima kasih Warga Tionghoa kepada Sri Sultan Hamengkubuwono. 
satu sisi BPN Kanwil harus tunduk pada kebijakan peraturan pertanahan nasional, namun di sisi lain kedudukan BPN Kanwil DIY berada di dalam teritorial wilayah kesultanan Yogyakarta yang memiliki aturan mainnya sendiri, sehingga cukup sulit bagi BPN menghadapi dua sistem hukum yang mendasari serta berlaku di wilayah tersebut. BPN Kanwil DIY menilai bahwa kebijakan pertanahan yang berlaku secara lokal di DIY memiliki sisi baik yakni melindungi tanahtanah di Wilayah DIY dari penguasaan secara berlebihan dari para investor yang memiliki kekuatan ekonomi jauh lebih baik ketimbang masyarakat lokal. Pada akhirnya, pihak BPN maupun PPAT di wilayah DIY, dengan keluarnya ketentuan ini memposisikan dirinya sebagai lembaga yang hanya sekedar melaksanakan ketentuan dan aturan yang telah ada di Yogyakarta.

\section{Hukum Antar Tata Hukum}

Berdasarkan uraian terkait fenomena sebagaimana terjadi di Wilayah DIY, hal tersebut dapat dipandang sebagai sebuah kondisi dimana terdapat lebih dari sebuah lingkungan kekuasaan hukum. Terkait IImu Lingkungan kekuasaan hukum dapat dikaji berdasarkan kajian Hukum Antar Tata Hukum. ${ }^{32}$ Hukum Antar Tata Hukum itu sendiri dibagi dalam dua bagian yakni Hukum Antar Tata Hukum Interen dan Hukum Antar Tata Hukum Eksteren. Terkait lingkungan kekuasaan hukum, terdapat 4 lingkungan kekuasaan atau rechtsgebieder (spheres) berlakunya hukum, yang pertama dinamakan lingkungan kuasa waktu (the sphere of time atau temporal sphere), kedua lingkungan kuasa tempat (territorial sphere atau sphere of space), ketiga lingkungan kuasa pribadi (personal sphere), dan keempat lingkungan kuasa soalsoal (zakengebied atau material sphere). ${ }^{33}$ Oleh karena terdapat lingkungan-lingkungan kekuasaan tersebut maka dapat dikertahui hukum harus bereja dalam jangka waktu mana, tempat mana, pribadi-pribadi orang mana, dan soal apa.

Hal-hal mengenai Hukum Antar Tata Hukum secara teoritis sangat erat kaitannya dengan Hukum Perdata International ("HPI"), bahkan ada beberapa teori yang mengatakan bahwa penyelesaian dari masalah-masalah Hukum Antar Golongan sebagai bagian dari Hukum Antar Tata Hukum dapat secara baik dicapai dengan menjiplak hasil-hasil dari HPI. ${ }^{34}$ Pendapat tersebut tidak sepenuhnya tepat, sebab berbicara mengenai HPI, maka akan lebih kontekstual apabila mengaitkannya dengan Hukum Antar Tempat, bukan Hukum Antar Golongan. Konteks HPI dalam hal ini mengacu pada hukum tempat atau teritorial yang bersangkutan. Baik Hukum Antar Tempat maupun HPI keduanya sama-sama merupakan "Hukum Perselisihan: yang menekankan atas adanya perbedaan-perbedaan hukum yang dikaitkan kepada teritorial tertentu, yang dapat secara geografis dibaca pada peta. ${ }^{35}$

Hukum Antar Tata Hukum Intern dibagi menjadi 3 (tiga) bagian berdasarkan lingkup kekuasaan hukumnya antara lain:

a) Hukum Antar Waktu

Hukum Antar Waktu adalah keseluruhan peraturan dan keputusan hukum yang menunjukkan hukum manakah yang berlaku

\footnotetext{
32 Sudargo Gautama, Pengantar Hukum Perdata Internasional Indonesia, (Bandung: Binacipta, 1987), hlm.12

33 Ibid.

34 Sudargo Gautama, Hukum Antar Tata Hukum, (Bandung: Alumi, 2005), hlm. 4.

35 Ibid.
} 
atau apakah yang merupakan hukum, jika hubungan-hubungan dan peristiwaperistiwa antara warga negara dalam satu negara dan satu tempat memperlihatkan titik-titik pertalian dengan stelsel-stelsel dan kaidah-kaidah hukum yang berbeda dalam lingkungan-lingkungan kuasa waktu dan soal-soal. ${ }^{36}$ Secara sederhana pengertian Hukum Antar Waktu dapat disimpulkan pada sebuah kondisi hukum dimana "waktunya" berbeda, tetapi "tempatnya" adalah bersamaan, sedangkan "pribadi" dan "soalsoalnya" berbeda. Contoh konkret dapat dilihat pada hukum perkawinan di Indonesia yang diatur sebelum Undang-Undang Nomor 1 Tahun 1974 tentang Perkawinan (UU No 1 Tahun 1974) yakni diatur dalam KUHPerdata dan setelah diundangankan serta diberlakukannya UU No.1 Tahun 1974. Berdasarkan contoh tersebut dapat dilihat dua dasar hukum berbeda yang berimplikasi pada implementasi hukum yang berbeda pula. Roh perkawinan di Indonesia berdasarkan KUHPerdata yang berlandaskan kultur dan budaya Masyarakat Eropa diubah dengan pranata UU No 1 Tahun 1974 yang kental nuansa Islamis. Menanggapi fenomena tersebut Pasal 64 UU No. 1 Tahun 1974 memberikan solusi pengaturan bahwa perkawinan dan segala sesuatu yang berhubungan dengan perkawinan yang terjadi sebelum Undang-Undang No. 1 Tahun 1974 diundangkan ialah sah dan tetap berlaku. ${ }^{37}$

b) Hukum Antar Tempat

Hukum Antar Tempat adalah keseluruhan peraturan dan keputusan hukum yang menunjukkan stelsel hukum manakah yang berlaku atau apakah yang merupakan hukum, jika hubungan-hubungan dan peristiwa-peristiwa antara warga (warga) negara dalam satu negara dan waktu tertentu memperlihatkan titik-titik pertalian dengan stelsel-stelsel dan kaidah-kaidah hukum yang berbeda dalam lingkunganlingkungan tempat, waktu, dan soal-soal. ${ }^{38}$ Permasalahan HukumAntarTempatinisangat kental dengan nuansa pluralisme hukum di Indonesia khususnya berbagai macam hukum adat yang ada. Hukum Antar Tempat apabila dilihat dari definisinya menunjukan permasalahan yang sangat mungkin terjadi di Indonesia pada masa sebelum adanya unifikasi hukum nasional Indonesia. Adanya interaksi antara masyarakat yang berasal dari lingkungan hukum adat yang berbeda mengakibatkan munculnya permasalahan Hukum Antar Tempat ini. Membahas mengenai Hukum Antar Tempat kita tidak dapat melepaskannya dari keterkaitan dengan pengaturan dalam Pasal 131 dan Pasal 163 Indische Staatsregeling ("IS") yang membagi penduduk Indonesia ke dalam beberapa golongan penduduk yang berimplikasi pada penerapan hukum adat bagi golongan bumiputera. Penerapan hukum adat tersebut berdampak pada ketidakadanya kepastian hukum apabila terjadi masalah antara dua penduduk yang memiliki hukum adat yang berbeda. Contohnya ialah dalam hukum perkawinan, apabila ada seorang yang berasal dari Suku Sunda hendak menikah dengan seorang yang berasal dari Suku Palembang, hukum

36 Sudargo Gautama, Pengantar Hukum Perdata Internasional, Op. Cit. hlm. 15.

37 Sudargo Gautama, Hukum Antar Tata Hukum, Op. Cit, hlm. 6.

38 Sudargo Gautama, Pengantar Hukum Perdata Internasional, Op. Cit. hlm. 18. 
manakah yang akan digunakan untuk perkawinan tersebut.

c) Hukum Antar Golongan

Hukum Antar Golongan adalah keseluruhan peraturan dan keputusan hukum yang menunjukkan stelsel hukum manakah yang berlaku atau apakah yang merupakan hukum, jika hubungan-hubungan dan peristiwaperistiwa antara warga negara dalam satu negara, satu tempat, dan satu waktu tertentu memperlihatkan titik-titik pertalian dengan stelsel-stelsel dan kaidah-kaidah hukum yang berbeda dalam lingkunganlingkungan pribadi dan soal-soal. ${ }^{39}$ Peristiwa konkret yang merupakan contoh Hukum Antar Golongan dapat ditemukan dengan mudah pada masa sebelum kemerdekaan Republik Indonesia. Sebagai implikasi hukum dari diberlakukannya Pasal 131 dan Pasal 163 Indische Staatsregeling, di Indonesia terdapat beberapa golongan penduduk yang masing-masing memiliki hukum yang berbeda-beda. Pembagian tersebut membawa dampak pada pemberlakuan hukum-hukum tertentu bagi golongangolongan masyarakat yang ada. Persitiwa terkait Hukum Antar Golongan muncul pada saat terjadi interaksi yang mengandung peristiwa hukum antar dua orang yang berasal dari golongan penduduk yang berbeda, seperti jual-beli antara penduduk dari Golongan Timur Asing dengan penduduk dari Golongan Bumiputera.

Apabila kemudian melihat tiga macam Hukum Antar Tata Hukum tersebut dapat diketahui bahwa hubungan yang terjadi antara subjek hukum terjadi di dalam satu wilayah negara tertentu. Hukum Antar Tempat bukanlah berarti bahwa terdapat perbedaan tempat, melainkan yang dimaksud Tempat dalam Hukum Antar Tempat ialah lingkungan tempat dalam satu wilayah kedaulatan sebuah negara. Seiring berjalannya waktu dimana Indonesia menjadi sebuah negara yang berdaulat dan merdeka maka tinjauan ketiga macam Hukum Antar Tata Hukum itu pun lama-kelamaan dianggap tidak lagi sesuai dengan kenyataan. ${ }^{40}$ Sejalan dengan kenyataan tersebut maka tinjauan Hukum Antar Tata Hukum dewasa ini lebih dititikberatkan pada konteks ruang kedaulatan sebuah negara, artinya bahwa Hubungan Antar Tata Hukum yang terjadi diartikan secara lebih meluas, yakni pada hubungan hukum antar negara berdaulat. Maka dari itu ragam Hukum Antar Tata Hukum sebagaimana dijelaskan sebelumnya dapat dikategorisasi ke dalam bentuk Hukum Antar Tata Hukum Interen yang dapat didefinisikan sebagai keseluruhan peraturan dan keputusan hukum yang menunjukkan stelsel hukum manakah yang berlaku atau apakah yang merupakan hukum, jika hubungan-hubungan dan peristiwa-peristiwa antara warga negara dalam satu negara memperlihatkan titik-titik pertalian dengan stelsel-stelsel dan kaidahkaidah hukum yang berbeda dalam lingkunganlingkungan tempat, waktu, dan soal-soal. ${ }^{41}$ Sebaliknya seiring dengan hubungan Hukum Antar Tata Hukum yang dewasa ini cenderung berkaitan dengan kedaulatan sebuah negara maka dikenal yang dinamakan Hukum Antar Tata Hukum Eksteren yang untuk selanjutnya juga

39 Sudargo Gautama, Pengantar Hukum Perdata Internasional, Op. Cit. hlm. 19.

40 Sudargo Gautama, Hukum Antar Tata Hukum, Op. Cit, hlm. 9.

41 Sudargo Gautama, Hukum Antar Golongan Suatu Pengantar, (Jakarta: Ichtiar Baru Van Hoeve, 1977), hlm.40. 
dikenal sebagai Hukum Perdata Internasional. Hukum Antar Tata Hukum Eksteren adalah keseluruhan peraturan dan keputusan hukum yang menunjukkan stelsel hukum manakah yang berlaku atau apakah yang merupakan hukum, jika hubungan-hubungan dan peristiwaperistiwa antara warga negara pada satu waktu tertentu memperlihatkan titik-titik pertalian dengan stelsel-stelsel dan kaidah-kaidah hukum dari dua atau lebih negara yang berbeda dalam lingkungan-lingkungan tempat, pribadi, dan soal-soal. ${ }^{42} \mathrm{Hal}$ yang paling membedakan antara Hukum Antar Tata Hukum Interen dan Hukum Antar Tata Hukum Eksteren ialah adanya foreign element dalam Hukum Antar Tata Hukum Eksteren yang diartikan adanya lebih dari satu negara dalam sebuah peristiwa. ${ }^{43}$

\section{Keberlakuan Instruksi Kepala Daerah DIY No K.898/I/A/1975 dan UU No 13 Tahun 2012 sebagai Perwujudan Hukum Antar Tata Hukum Intern}

Fenomena keberlakuan Instruksi Kepala Daerah DIY No K. 898/I/A/1975 di Wilayah DIY merupakan sebuah hal yang dapat dicermati dari sudut pandang kajian Hukum Antar Tata Hukum Interen, khususnya Hukum Antar Waktu. Sebagaimana telah dijelaskan sebelumnya, Hukum Antar Waktu adalah Hukum Antar Waktu adalah keseluruhan peraturan dan keputusan hukum yang menunjukkan hukum manakah yang berlaku atau apakah yang merupakan hukum, jika hubungan-hubungan dan peristiwaperistiwa antara warga (warga) negara dalam satu negara dan satu tempat memperlihatkan titik-titik pertalian dengan stelsel-stelsel dan kaidah-kaidah hukum yang berbeda dalam lingkungan-lingkungan kuasa waktu dan soalsoal. ${ }^{44}$ Apabila dilihat keberlakuan Instruksi Kepala Daerah DIY No K. 898/I/A/1975 di Wilayah DIY merupakan sebuah fenomena yang pada prinsipnya bertentangan dengan hukum positif yang berlaku di Republik Indonesia. Hal ini tidak dapat dilepaskan pula dari ketentuanketentuan dalam UU No. 13 Tahun 2012 tentang Keistimewaan Daerah Istimewa Yogyakarta. Peraturan ini secara khusus memberikan kewenangan-kewenangan tertentu bagi Pemerintah Provinsi DIY untuk mengurus sendiri urusan-urusan yang ditentukan dalam peraturan tersebut. Adapun kewenangan-kewenangan tersebut ialah kewenangan mengurus hal-hal pemerintahan yang berkaitan dengan tata cara pengisian jabatan, kedudukan tugas, dan wewenang Gubernur dan Wakil Gubernur, kelembagaan Pemerintah DIY, kebudayaan, pertanahan, dan tata ruang. ${ }^{45}$ Sebagaimana diatur pada Pasal 7 ayat (2) UU No. 13 Tahun 2012, pertanahan menjadi salah satu bidang dimana wewenang pengaturannya diserahkan kepada pemerintah daerah. Menurut Sudikno Mertokusumo, di daerah Swapraja Yogyakarta dan Surakarta, tanah adalah milik raja dan ia berkuasa penuh atas tanah-tanah yang mana sebagian dari tanah-tanah itu dikuasai oleh raja yang merupakan tanah domein. ${ }^{46}$ Secara historis, wewenang untuk mengurus soal pertanahan tersebut tidak dapat dilepaskan

Sudargo Gautama, Pengantar Hukum Perdata Internasional, Op. Cit. hlm. 21.

Ibid.

44 Sudargo Gautama, Pengantar Hukum Perdata Internasional, Op. Cit. hlm. 15.

45 Indonesia, Undang-Undang Tentang Keistimewaan Daerah Istimewa Yogyakarta, Undang-Undang UU No 13 Tahun 2012, LN Tahun 2012 No 170 TLN. 5339, Pasal 7.

46 Sudikno Mertokusumo, Peraturan Perundang-Undangan Agraria Indonesia, Cet Kedua, (Yogyakarta; Liberty, 1982), hlm. 28. 
dari UU No. 3 Tahun 1950 tentang Pembentukan Daerah Istimewa Jogjakarta. Secara spesifik Pasal 4 UU No. 3 Tahun 1950 memberikan amanat kepada pemerintah daerah Yogyakarta untuk mengurus sendiri urusan-urusan yang mencakup di dalamnya ialah urusan agraria. ${ }^{47}$ Adapun keistimewaan tersebut tidak serta merta muncul tanpa dasar yuridis yang kuat, melainkan pada tahun 1948 pernah diundangkan UU No. 22 Tahun 1948 tentang Penetapan Aturan-Aturan Pokok Mengenai Pemerintahan Sendiri Daerah-Daerah yang berhak mengatur rumah tangganya sendiri, yang mana konsep tersebut saat ini diimplementasikan dengan prinisp otonomi daerah sebagaimana diatur dalam Undang-Undang Nomor 32 Tahun 2004 Tentang Pemerintahan Daerah (UU No 32 Tahun 2004), yang mana dalam ketentuan ini dikenal istilah yang disebut sebagai desentralisasi. Desentralisasi adalah penyerahan wewenang pemerintahan oleh Pemerintah kepada daerah otonom untuk mengatur dan mengurus urusan pemerintahan dalam sistem Negara Kesatuan Republik Indonesia ${ }^{48}$. Pada Undang-Undang ini juga diatur mengenai jenis-jenis urusan pemerintahan yang mengamanatkan bahwa pemerintahan daerah dapat menyelenggarakan urusan pemerintahan yang menjadi kewenangannya, kecuali urusan pemerintah yang ditentukan menjadi urursan Pemerintah. Adapun urusan pemerintahan yang menjadi urusan Pemerintah ialah sebagai berikut: ${ }^{49}$ politik luar negeri, pertahanan, keamanan, yustisi, moneter dan fiskal nasional, dan agama. Urusan-urusan tersebutlah yang wajib diselenggarakan oleh pemerintah pusat dan tidak dapat diwakillkan kepada pemerintah daerah sedangkan untuk hal-hal lainnya dimungkinkan untuk diselenggarakan oleh pemerintah daerah.

Sejak diundangkannya UU No. 5 Tahun 1960, dan tidak ada lagi penggolongan penduduk di Indonesia, seharusnya telah terjadi unifikasi hukum pertanahan di Wilayah Republik Indonesia. Seluruh wilayah yang termasuk ke dalam teritorial Wilayah Republik Indonesia wajib dan tunduk pada ketentuan hukum nasional. Apabila dikaitkan dengan teori mengenai Hukum Antar Waktu, keberlakuan Instruksi Kepala Daerah DIY No. K. 898/I/A/1975 dan UU No. 5 Tahun 1960 dapat dikatakan sebagai dua lingkungan waktu dan soal-soal yang berbeda. Lingkungan kuasa waktu yang berbeda dapat dilihat pada keberlakuan kedua peraturan tersebut. Instruksi Kepala Daerah DIY No. K. 898/I/A/1975 berlaku di Wilayah DIY sebelum akhirnya melalui Kepres No 33 Tahun 1984, UU No 5 Tahun 1960 diberlakukan secara penuh di Wilayah DIY. Terbitnya Kepres No. 33 Tahun 1984 seharusnya menandakan perubahan ketentuan pertanahan di Wilayah DIY sehingga mengikuti ketentuan hukum agraria nasional.

Secara sosiologis sebagaimana telah dijelaskan, di Wilayah DIY masih terjadi perbedaan perlakuan khususnya berkaitan dengan pemberian Hak Atas Tanah bagi WNI Keturunan Tionghoa. Perbedaan perlakuan tersebut seharusnya sudah tidak terjadi lagi seiring dengan berlakunya UU No. 5 Tahun 1960 di Wilayah DIY namun pada praktiknya

\footnotetext{
47 Indonesia, Undang-Undang Tentang Pembentukan Daerah Istimewa Jogjakarta, Undang-Undang No 3 Tahun 1950, Berita Negara Republik Indonesia Tahun 1950 No 3,Pasal 4.

48 Indonesia, Undang-Undang Tentang Pemerintahan Daerah, Undang-Undang UU No 23 Tahun 2004, LN Tahun 2004 No 125 TLN. 4437, Pasal 1 angka 7

49 Pasal 10 ayat (3), Ibid.
} 
Instruksi Kepala Daerah DIY No K. 898/I/A/1975 masih dijadikan pijakan bagi para pemangku kepentingan di bidang pertanahan guna memberikan Hak Atas Tanah. Terkait dengan praktik Hukum Antar Waktu dapat dilihat contoh di bidang hukum perkawinan, yakni pada Pasal 64 UU No. 1 Tahun 1974 terdapat ketentuan peralihan yakni segala sesuatu yang berhubungan dengan perkawinan yang terjadi sebelum Undang-Undang yang baru ini berlaku, yang dijalankan menurut peraturanperaturan lama, merupakan perkawinan yang sah. ${ }^{50}$ Contoh Hukum Antar Waktu yang berkaitan dengan Hukum Perkawinan sebelum diundangkannyaUUNo.1Tahun 1974dan setelah diundangkannya Undang-Undang tersebut tidak memicu munculnya konflik hukum berkenaan dengan Hukum Antar Waktu, sebab dalam UU No. 1 Tahun 1974 sudah diberikan dasar hukum yang kuat dalam ketentuan peralihan. Berkenaan dengan praktik hukum pertanahan Pasal 58 UU No. 5 Tahun 1960 mengatur bahwa selama peraturan-peraturan pelaksanaan Undang-Undang ini belum terbentuk, maka peratura-peraturan baik yang tertulis maupun yang tidak tertulis mengenai bumi dan air serta kekayaan alam yang terkandung di dalamnya dan hak-hak atas tanah yang ada pada mulai berlakunya Undang-Undang ini, tetap berlaku, sepanjang tidak bertentangan dengan jiwa dari ketentuan-ketentuan dalam Undang-Undang ini serta diberi tafsiran yang sesuai dengan itu. Sehubungan dengan potensi munculnya masalah Hukum Antar Waktu, Pasal 58 UU No. 5 Tahun 1960 tersebut hanya memberikan aturan sejauh tidak bertentangan dengan jiwa dari ketentuan-ketentuan dalam Undang-
Undang ini. Sebagai pelaksanaannya Keppres No. 33 Tahun 1984 pun tidak mengatur soal pemberian Hak Atas Tanah. Tidak adanya aturan peralihan yang jelas terkait pemberian Hak Atas Tanah berimplikasi pada peraturanperaturan terdahulu di bidang pertanahan masih terus berlaku dan diimplementasikan di Wilayah DIY salah satunya ialah Instruksi Kepala Daerah DIY No. K. 898/I/A/1975. Selain tidak adanya aturan peralihan menyangkut kebijakan pertanahan di Wilayah DIY, Pasal 7 ayat (2) huruf d UU No. 13 Tahun 2012 yang mengatur salah satu kewenangan istimewa dari DIY ialah untuk mengatur soal pertanahan juga dijadikan salah satu landasan yuridis terkait keberlakuan Instruksi Kepala Daerah DIY No. K.898/I/A/1975 sejauh tetap memperhatikan kaidah-kaidah dalam penyelenggaraan otonomi daerah dan otonomi tidak diartikan sebagai vrije beweging yang seluas-luasanya sebagaimana dijelaskan oleh Logemann. Vrije beweging ialah kekuasaan bertindak memerintah sendiri, yang dapat dipergunakan untuk menyelenggarakan kepentingan umum. Selain faktor yuridis postivis, perkembangan sejarah Pasal 7 ayat (2) huruf d UU No. 13 Tahun 2012 juga menjadi salah satu pertimbangan historis terkait keberlakuan Instruksi Kepala Daerah DIY No. K.898/I/A/1975. Sebagaimana telah dijelaskan sebelumnya, bahwa Pasal 7 ayat (2) huruf d UU No. 13 Tahun 2012 merupakan pembaruan dari Pasal 4 UU No. 3 Tahun 1950 yang memberikan amanat kepada pemerintah daerah Yogyakarta untuk mengurus sendiri urusan-urusan yang mencakup di dalamnya ialah urusan agraria. ${ }^{51}$ Apabila dilihat berdasarkan teori perundang-undangan maka seiring dengan diundangkannya UU No. 5

50 Sudargo Gautama, Hukum Antar Tata Hukum, Op. Cit, hlm. 6.

51 Indonesia, Undang-Undang Tentang Pembentukan Daerah Istimewa Jogjakarta, Op. Cit, Pasal 4. 
Tahun 1960 seharusnya telah terjadi unifikasi di bidang hukum pertanahan di Indonesia dan kebijakan yang merupakan implementasi dari Instruksi Kepala Daerah DIY No. K.898/I/A/1975 seharusnya tidak dapat diberlakukan kembali namun dalam hal ini teori positivisme hukum seolah sedikit bergeser ke arah teori pluralisme hukum yang memungkinkan adanya lebih dari satu sistem hukum yang hidup di dalam masyarakat khususnya demi menyelenggarakan kepentingan umum. Teori pluralisme hukum tersebut sesuai dapat dipahami melalui pendekatan sosio-legal dimana pendeketan ini harus digunakan mengingat konteks hukum Surat Instruksi Kepala Daerah DIY No. K. 898/I/A/1975 tidak terlihat jelas sebagai hukum negara, tetapi keberadaan sistem hukum secara bersama-sama itu (hukum negara dan hukum adat) menunjukkan adanya saling difusi, kompetisi, dan tentu saja perubahan sepanjang waktu. Hal ini menyebabkan bahwa antara hukum negara dan hukum rakyat tidak terlihat adanya perbedaan yang mendasar. ${ }^{52}$ Alasan itulah yang menyebabkan Surat Instruksi Kepala Daerah DIY No K. 898/I/A/1975 masih dianggap berlaku baik secara yuridis, sosiologis, dan filosofis sebagaimana dapat dilihat pada Surat Keterangan yang dikeluarkan Pemerintah Provinsi DIY tertanggal 8 Mei 2012 No: 593/00531/RO.I/2012. ${ }^{53}$

Selain dari sudut pandang Hukum Antar Waktu, implementasi Instruksi Kepala Daerah DIY No. K.898/I/A/1975 juga mengandung unsur Hukum Antar Golongan. Sebagaimana diketahui Hukum Antar Golongan adalah keseluruhan peraturan dan keputusan hukum yang menunjukkan stelsel hukum manakah yang berlaku atau apakah yang merupakan hukum, jika hubungan-hubungan dan peristiwaperistiwa antara warga (warga) negara dalam satu negara, satu tempat, dan satu waktu tertentu memperlihatkan titik-titik pertalian dengan stelsel-stelsel dan kaidah-kaidah hukum yang berbeda dalam lingkungan-lingkungan pribadi dan soal-soal. ${ }^{54}$ Berdasarkan definisi Hukum Antar Golongan, Instruksi Kepala Daerah tersebut mengandung norma yang memungkinkan terjadinya interaksi antara Golongan Timur Asing dan Golongan Bumiputera khususnya dalam bidang pertanahan.

\section{Titik Taut Primer dan Titik Taut Sekunder}

Pada kajian Hukum Antar Tata Hukum dikenal adanya dua macam titik taut yakni titik taut primer dan titik taut sekunder. Titik Taut Primer atau Titik Taut Pembeda ialah faktorfaktor dan keadaan-keadaan yang menciptakan bahwa suatu hubungan menjadi hubungan Hukum Antar Tata Hukum. ${ }^{55}$ Sedangkan Titik Taut Sekunder atau Titik Taut Penentu ialah titik taut yang menentukan hukum mana yang harus diberlakukan. ${ }^{56}$ Titik Taut Primer merupakan alatalat pertama guna pelaksana hukum khususnya bagi hakim dalam menentukan hukum mana yang dapat digunakan. Dalam bidang Hukum Antar Golongan atau Hukum Antar Tata Hukum Intern dikenal adanya beberapa Titik Taut Primer

\footnotetext{
52 Sulistyowati Irianto,"Pluralisme Hukum dalam Perspektif Globall”. Dalam Adrian Bedner, dkk (Ed), Kajian SosioLegal, (Jakarta: Pustaka Larasan, 2012), hlm. 166.

53 Surat Keterangan Pemerintah Provinsi DIY No: 593/00531/RO.I/2012, Op. Cit.

54 Sudargo Gautama, Pengantar Hukum Perdata Internasional, Op. Cit. hlm. 19.

55 Sudargo Gautama, Pengantar Hukum Perdata Internasional, Op. Cit. hlm. 25.

56 Ibid.
} 
antara lain para pihak-pihak (partijen), subjeksubjek hukum, tanah, pilihan hukum, dan hakim. ${ }^{57}$ Setelah diketahui Titik Taut Primer yang membedakan sebuah peristiwa dapat dikatakan sebagai hubungan Hukum Antar Tata Hukum Intern maka penting juga untuk mengetahui hukum manakah yang dapat digunakan. Faktorfaktor yang menentukan hukum manakah yang harus dipilih daripada stelsel-stelsel hukum yang dipertautkan inilah yang dinamakan titik taut sekunder. ${ }^{58}$ Titik Taut Sekunder di dalam kajian Hukum Antar Tata Hukum Interen tidak diatur secara tertulis dalam peraturan perundang-perundangan. Titik Taut Sekunder dapat disimpulkan dari beberapa putusan hakim terdahulu yang memutuskan perkara soal pilihan hukum mana yang digunakan antara lain: maksud para pihak, milieu, kedudukan masyarakat yang jauh melebihi dari salah satu pihak, masuk dalam suasana hukum pihak yang lain, dan tanah pada perjanjian obligatoir. ${ }^{59}$

Terkait keberlakuan Instruksi Kepala Daerah DIY No. K.898/I/A/1975 di Wilayah DIY dapat dilihat bahwa persoalan pokok yang terkandung di dalamnya ialah mengenai sebuah peraturan yang mengatur soal pertanahan, sehingga dapat dikatakan bahwa secara persoalan keberlakuan instruksi tersebut ialah persoalan Hukum Antar Tata Hukum Interen. Tanah dalam hal ini mempunyai suatu "statuut" tersendiri terlepas daripada hukum orang yang memegangnya. Asas ini dikenal dengan intergentiele grondenregel. ${ }^{60}$ Asas ini mengatur bahwa tanah seoalah-olah mempunyai golongan rakyat tersendiri. Pasal 17 Alegemeene Bepalingen van Wetgeving ("AB") merupakan salah satu dasar hukum yang berkaitan dengan pengembangan asas tersebut dalam ranah Hukum Antar Tata Hukum Ekstern dimana diatur Terhadap benda-benda tetap (tidak bergerak) berlaku perundang-undangan negara atau tempat dimana benda-benda itu terletak. Selain itu menurut Klein dan Wertheim, status tanah menentukan segala perbuatan hukum terkait tanah tersebut. ${ }^{61}$ Asas intergentiele grondenregel ini secara teoritis membuka kemungkinan terjadinya perbedaan hukum yang berlaku antara sebidang tanah dengan subjek hukum yang menguasai tanah tersebut. Apabila ditinjau menurut sejarah pertanahan asas ini mengingatkan akan penerapan beberapa macam tanah yang perna berlaku di Indonesia yakni: Tanah Eropa (yang terdaftar menurut Overschrijvingsordonnantie), Tanah Indonesia (di bawah hukum adat), dan Tanah Tionghoa (misalnya landerijenbezitrecht). ${ }^{62}$

Menurut asas intergentiele grondenregel masing-masing jenis tanah tersebut hanya dapat diletakkan hak-hak atas tanah yang masing-masing sudah ditentukan menurut golongannya. Asas ini tidak diatur secara jelas dan tertulis dalam peraturan perundangundangan, namun pada praktiknya asas ini terus berkembang dan tumbuh dalam masyarakat, misalnya dalam hal Tanah Eropa dijual kepada orang Indonesia yang menyebabkan orang Indonesia sebagai pemilik tanah baru memiliki hukum yang berbeda dengan tanah yang

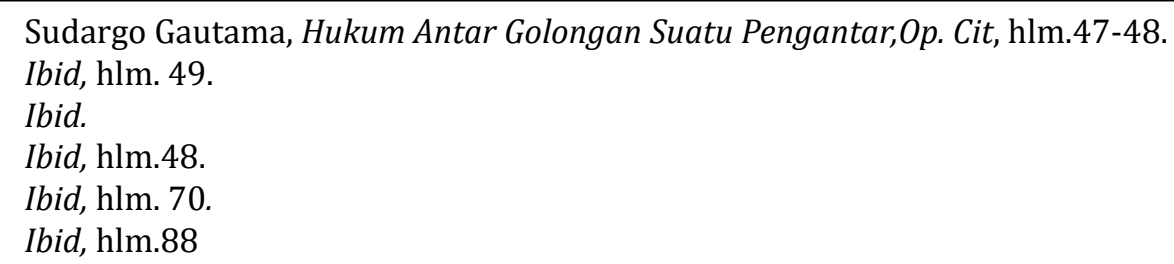


dimilikinya. Guna mengantisipasi terjadinya hal-hal demikian pemerintah colonial pernah mengeluarkan beberapa regulasi yang menjadi acuan agar asas intergentiele grondenregel tidak menjadi persoalan seperti: Staatblaad 1875/179, Staatblaad 1872/117, Staatblaad 1906/431, Staatblaad 1912/442, Staatblaad 1915/98, Staatblaad 1913/702, Staatblaad 1912/422, dan Staatblaad 1923/475. ${ }^{63}$

\section{Penutup}

Penerapan Instruksi Kepala Daerah DIY No. K. 898/I/A/1975 di Wilayah DIY merupakan bentuk Hukum Antar Tata Hukum Interen khususnya Hukum Antar Waktu yang masih terjadi di Indonesia pasca kemerdekaan Republik Indonesia. Kecenderungan kajian Hukum Antar Tata Hukum Intern yang dewasa ini tergantikan dengan Hukum Antar Tata Hukum Eksteren atau Hukum Perdata Internasional muncul kembali sejalan dengan fenomena Keberlakuan Instruksi Kepala Daerah DIY No. K. 898/I/A/1975 di Wilayah DIY. Keberlakuan Instruksi Kepala Daerah DIY No. K. 898/I/A/1975 dan Keberlakuan Hukum Positif saat ini yakni UU No. 5 Tahun 1960 dapat dikatakan sebagai dua lingkungan waktu dan soal-soal yang berbeda. Lingkungan kuasa waktu yang berbeda dapat dilihat pada keberlakuan kedua peraturan tersebut dimana UU No. 5 Tahun 1960 sudah tidak membedakan adanya penggolongan penduduk WNI pribumi dan WNI non pribumi sedangkan Instruksi Kepala Daerah DIY No. K. 898/I/A/1975 masih menganut prinsip penggolongan penduduk yang mengenal pembagian penduduk pribumi dan non pribumi. Selain sebagai Hukum Antar Waktu, fenomena tersebut dapat pula ditinjau dari segi Hukum Antar Golongan dimana apabila ditinjau berdasarkan titik taut yang dikenal dalam teori Hukum Antar Tata Hukum maka dapat diketahui bahwa penerapan Instruksi Kepala Daerah DIY No. K. 898/I/A/1975 sudah sesuai dengan asas intergentiele grondenregel yang secara asas mendukung keistimewaan DIY dalam mengurus soal pertanahan sebagaimana diatur dalam Pasal 7 ayat (2) UU No. 13 Tahun 2012 dan secara historis telah melembaga pada pemerintahan DIY sejak awal pendirian DIY sebagaimana diatur dalam UU No. 3 Tahun 1950. Adapun permasalahan terkait keberlakuan Instruksi Kepala Daerah DIY No. K. 898/I/A/1975 seharusnya sudah dapat terselesaikan sejalan dengan telah diundangkannya Perda Istimewa DIY yang mengatur mengenai pertanahan pada tahun 2017, namun secara keseluruhan Perda Istimewa tersebut belum mampu menjawab permasalahan mengenai penerapan Instruksi Kepala Daerah DIY No. K. 898/I/A/1975 secara mendasar terlebih soal kepemilikan Hak Milik Atas Tanah bagi WNI keturunan Tionghoa. Perda Istimewa yang mengatur soal pertanahan di Wilayah DIY seharusnya mampu memaparkan dan menyelesaikan persoalan tersebut baik secara sosiologis, historis, dan yuridis dengan mempertimbangkan intergentiele grondenregel sehingga dalam pelaksanaan tidak lagi terjadi ketidakpastian hukum terkait pertanahan di Wilayah DIY khususnya bagi WNI Keturunan Tionghoa yang selama ini merasa digantungkan nasibnya.

\section{Daftar Pustaka}

\section{Buku}

Banakar, Reza and Max Travers, Theory and Method in Socio-Legal Research, (Portland: Hart Publishing Oxford and Portland, 2005).

63 Ibid, hlm. 90. 
Gautama, Sudargo, Tafsiran Undang-Undang Pokok Agraria, (Bandung: IKAPI, 1990).

Gautama, Sudargo, Masalah Agraria, (Bandung: Alumni, 1997).

Gautama, Sudargo, Pengantar Hukum Perdata Internasional Indonesia, (Bandung: Alumni. 1997).

Gautama, Sudargo, Hukum Antar Golongan Suatu Pengantar, (Jakarta: Ichtiar Baru Van Hoeve, 1993).

Gautama, Sudargo, Hukum Perdata Internasional Indonesia Jilid 2, (Jakarta: Kinta Jakarta, 1972).

Gautama, Sudargo, Hukum Antar Tata Hukum, (Bandung: Alumni, 1973).

Harsono, Budi, Menuju Penyempurnaan Hukum Tanah Nasional, (Jakarta: Penerbit Universitas Trisakti, cet. II, 2003).

Harsono, Budi, Hukum Agraria Indonesia Sejarah Pembentukan Undang-Undang Pokok Agraria, Isi, dan Pelaksanaannya, (Jakarta: Djambatan, cet. 12, 2008).

Mertokusumo, Sudikno, Peraturan PerundangUndangan Agraria Indonesia, (Yogyakarta: Liberty, cet. II, 1982).

Plato, Republik, (Yogyakarta: Pustaka Promethea, cet. I, 2015).

Purbacaraka, Purnadi dan Ridwan Halim, Hak Milik Keadilan dan Kemakmuran Tinjauan Falsafah Hukum, (Jakarta: Rajawali Pers, cet. II, 1991).

Purbacaraka, Purnadi dan Soerjono Soekanto, Ikhtisar Antinomi Nilai Aliran Filsafat Sebagai Landasan Filsafat Hukum, (Jakarta: Rajawali Pers, cet. II, 1991).

Praptodihardjo, Singgih, Sendi-Sendi Hukum Tanah di Indonesia, (Jakarta: Yayasan Pembangunan, 1953).

Purbacaraka, Purnawidhi W., Filsafat Hukum (Aspek Etis), (Depok: Djokosoetono Research Center FHUI, cet. 1, 2011).

Radjagukguk, Erman, Hukum Agraria, Pola Penguasaan Tanah dan Kebutuhan Hidup. (Jakarta: Chandra Pratama, 1995).
Schlatter, Richard, Private Property, The History of an Idea", (London: George Allen \& Unwin Ltd, ed. I, 1951).

Sidharta, Bernard A., "Penelitian Hukum Normatif: Analisis Penelitian Filosofikal dan Dognatikal" dalam Sulistyowati Irianto dan Shidarta (Ed), Metode Penelitian Hukum Konstlelasi dan Refleksi, (Jakarta: Yayasan Pustaka Obor, 2009).

Soekanto, Soerjono, Pengantar Penelitian Hukum, (Jakarta: UI Press, cet. 1, 2010).

\section{Internet}

http://www.indonesia.go.id/in/sekilas-indonesia/ geografi-indonesia, (diakses 10 September 2015).

http://kbbi.web.id/diskriminasi, (diakses 16 September 2015).

\section{Peraturan}

Undang-Undang Nomor 5 tahun 1960 tentang Pokok-Pokok Agraria.

Undang-Undang Nomor 13 tahun 2012 tentang Keistimewaan Daerah Istimewa Yogyakarta.

Undang-Undang Nomor 12 Tahun 2006 Tentang Kewarganegaraan.

Undang-Undang Nomor 12 Tahun 2011 tentang Pembentukan Peraturan Perundang-Undangan.

Undang-Undang Nomor 3 Tahun 1950 tentang Pembentukan Daerah Istimewa Jogjakarta.

Ketetapan MPR Nomor II/MPR/1993 tentang GarisGaris Besar Haluan Negara,.

Surat Instruksi Kepala Daerah Istimewa Yogyakarta Nomor K. 898/I/A/1975 Mengenai Penyeragaman Policy Pemberian Hak Atas Tanah Kepada Seorang WNI non Pribumi.

Perda DIY Nomor 3 Tahun tentang Pelaksanaan Berlaku Sepenuhnya Undang-Undang No 5 Tahun 1960 di Propinsi DIY. 